\title{
Seaward pinching out and internal stratigraphy of the Gironde incised valley on the shelf (Bay of Biscay)
}

\author{
Gilles Lericolais*, a , Serge Berné, a and Hugues Féniès' b
}

\author{
a : Laboratoire de Environnements Sedimentaires, IFREMER, Centre de Brest, DRO-GM, BP 70, F-29280 \\ Plouzané cedex, France \\ b : ESSO-Rep, 213 cours Victor Hugo, F-33321 Bègles cedex, France
}

*: Corresponding author : Tel.: +33-298-22-42-48; fax: +33-298-22-45-70; email: gilles.lericolais@ifremer.fr

\begin{abstract}
:
An incised paleovalley offshore the estuary mouth of the Gironde River (Southwest France) was evidenced recently (Comptes Rendus de l'Académie des Sciences de Paris 326 (1998) 701). Nevertheless its seaward extension to the shelf break was still unknown. New high-resolution geophysical data were acquired on the continental shelf in order to follow the incision until the shelf break. After processing the seismic lines, the shape of the valley was identified and the valley-fill in terms of sequence stratigraphy was interpreted.
\end{abstract}

The valley-fill contains a single sequence corresponding to a fifth-order cycle (20 kyr). The three Systems Tracks described onshore by Allen and Posamentier (Journal of Sedimentary Petrology 63 (1993) 378; SEPM (Society for Sedimentary Geology) Special Publication, Tulsa (1994) 225) are present offshore. The Lowstand is poorly developed and is only present in the proximal part of the incised-valley. The Transgressive Systems Tract (TST) constitutes the bulk of the valley-fill, it is composed of landward-prograding estuarine clinoforms in the distal part of the valley (early TST, phase 1) and of landward-migrating tidal inlet-fill deposits in the proximal part of the valley (late TST, phase 2). The thin early Highstand Systems Tracts (HST) strata downlap seaward onto the maximum flooding surface and caps the TST. As expected in this wave- and tide-dominated environment, the tidal -and wave-ravinement surfaces, which bound the TST, are particularly well developed.

The valley incision tapers $50 \mathrm{~km}$ offshore of the estuary mouth: the depth of the basal sequence boundary gradually decreases seaward and is locally truncated by the wave-ravinement surface around $-70 \mathrm{~m}$ below the mean sea-level. These observations indicate that during the Lowstand times, rivers do not always generate continuous cross-shelf incised-valleys. They may adjust to a rapid drop in base level by modifying their channel morphology (i.e. deep large channels located upstream change downstream to shallow anastomosed channels with a weaker erosional ability). Therefore, the Lowstand fluvial channels will be poorly developed, and will eventually died out in the proximal part of the shelf because they are unable to keep pace with a phase of rapid sea-level drop. Similar observations have already been reported for the English Channel paleoriver (Geological Society Special Publication, London (1996) 203; Thèse de Géologie Marine, Université de Bordeaux 1 (1997) 265).

Keywords: Incised valley-fill; Sequence stratigraphy; Estuary; High resolution seismic data 


\section{Introduction}

Incised valley-fill architecture has been widely analysed both on modern and ancient settings throughout the last decade. An incised-valley system, composed of an incised valley and of its depositional fill, may provide a good evidence of lowstand to transgressive deposition in shelf-slope and/or shallow-ramp, marine depositional settings (Allen and Posamentier, 1993; 1994; Belknap et al., 1994; Suter et al., 1987; Thomas and Anderson, 1994; Van Wagoner et al., 1990; Zaitlin et al., 1994). Estuarine deposits are a major constituent of incised-valley systems. There have been many examples of stratigraphical studies of modern micro-wave-dominated incised valley estuaries (Boyd and Honig, 1992; Dalrymple et al., 1992, 1994a and b; Demarest and Kraft, 1987; Knebel et al., 1988). On the other hand, one of the most well-known sequence stratigraphical interpretation existing for modern macrotidal estuary study is the one which has been documented for the onshore part of the Gironde Estuary (SW France) by Allen and Posamentier (Allen, 1991; Allen and 1993, 1994).

Till now, because of the lack of very high-resolution seismic profiles on the shelf and due to the high energy wave regime that affects this coastline, the depth of incision of the valley and the nature of its fill seaward of the estuary were still unknown. Due to improvement in acquisition and processing of very high resolution seismic data (i.e. swell filtering and multiple removal, Girault and Mathevon, 1990; Lericolais et al., 1990; 1991; 1994a and b), new information were obtained during a cruise carried out by IFREMER in 1995, on board the R/V "Thalia", devoted to identify the offshore extension of the Gironde incised valley. The seismic profiles were shot from the inner Gironde estuary to the outer part in order to follow the incision itself. The incision has been evidenced inside the estuary by numerous studies during the past 30 years (Fig. 1). Early studies of the abundant boreholes available within the estuary (Allen et al., 1970; Assor, 1972; Fabre, 1939; Feral, 1970), indicated that the modern estuary overlies a late-Pleistocene, fluvial incised valley cut into Miocene sediments. 


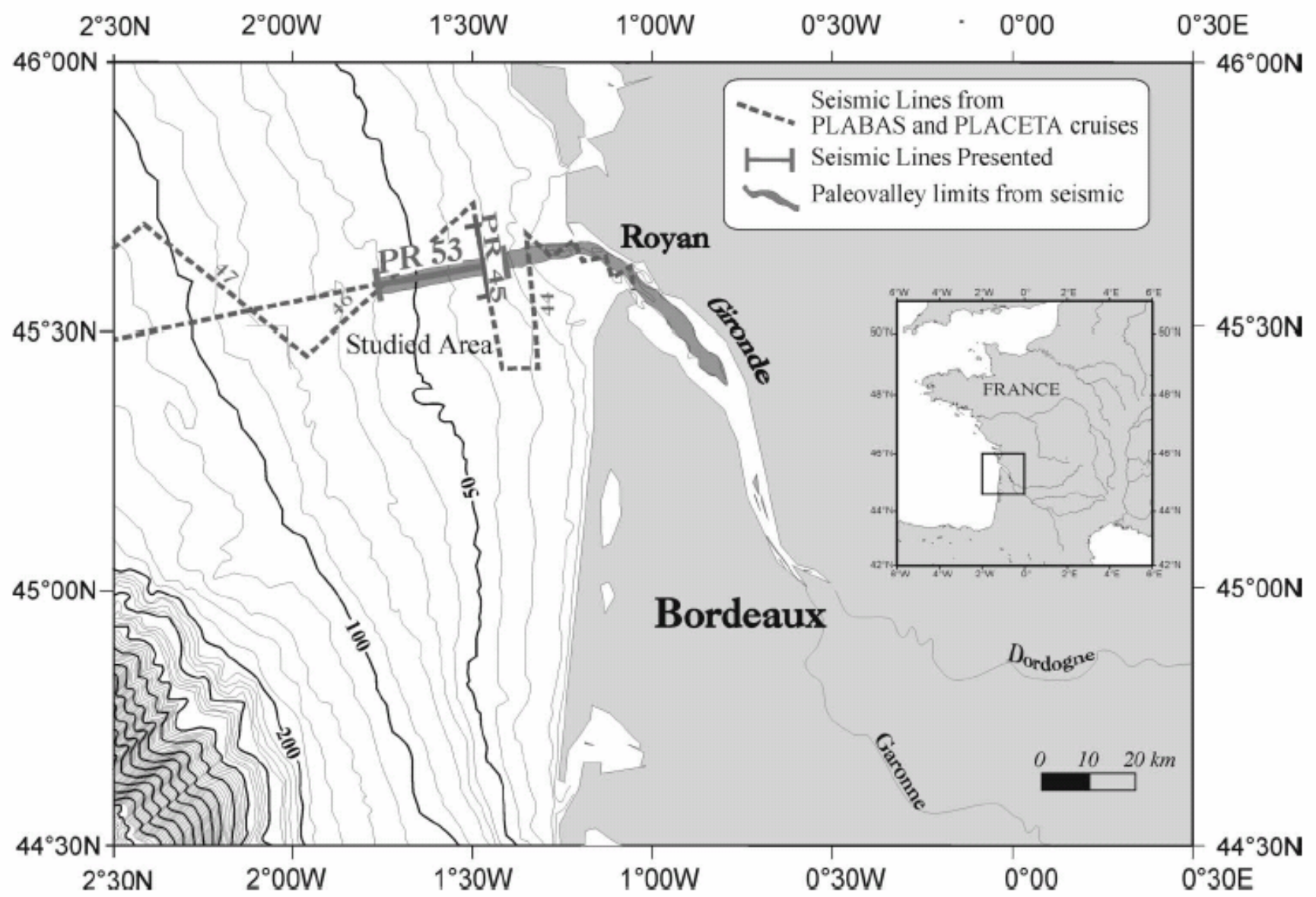

Figure 1: a) Map of Southwest France showing location of the Gironde Estuary.

b) Location of the "PLACETA" and "PLABAS" surveyed area. 
This paper provides a detailed stratigraphic description of an estuarine incised valley-fill in a wave -and tide- dominated environment :

(1) A transverse section of the offshore portion of the Gironde incised valley (Lericolais et al., 1998) confirms the assumptions made by Allen and Posamentier $(1993,1994)$ for the offshore stratigraphy of the valley-fill. On this section, several important surfaces within the valley-fill are recognised and could correspond to : the Sequence Boundary (SB), the transgressive surface (TS), the tidal-ravinement surface (TRS), the wave-ravinement surface (WRS) and the maximal flooding surface (MFS).

(2) A longitudinal section obtained seaward of the estuary mouth along the axis of the valley shows that the valley incision tapers $50 \mathrm{~km}$ offshore.

The rough weather conditions and the high energy wave regime outside the mouth estuary are responsible of the poor quality of the seismic results, the lines presented are the best in quality and the most meaningful from our data set to explain one of the reason why after many surveys on the Bay of Biscay continental shelf, the Gironde valley prolongation was never described.

\section{Regional setting}

\section{1 - Hydrodynamic characteristics of the Gironde estuary :}

The Gironde Estuary flows into the Bay of Biscay (south-west of France), and results in the merging of the Garonne and Dordogne rivers (Fig. 1). It drains a basin of approximately 75,000 $\mathrm{km}^{2}$ including the western part of the Massif Central, and the northern part of the Pyrénées mountains. The annual water discharges is between 2.5 and $3.5 \times 10^{10} \mathrm{~m}^{3}$. The winter mean flood discharge is approximately $1.4 \times 10^{3} \mathrm{~m}^{3} \mathrm{~s}^{-1}$ with exceptional flood discharges attaining $7.5 \times 10^{3} \mathrm{~m}^{3} \mathrm{~s}^{-1}$ (Allen, 1972).

In the estuary mouth, tidal range is comprised between $2 \mathrm{~m}$ (neap tide) and $5 \mathrm{~m}$ (spring tide). The bottom tidal current velocities exceed 0.5 m.s- 1 in the Gironde inlet, but decrease rapidly on the inner shelf (Lesueur and Tastet, 1994). Another essential hydrodynamic feature 
of this shelf is its exposure to the west-northwest large-amplitude and long-period swells : wave amplitude reaches a maximum of $9 \mathrm{~m}$ one day yearly, an amplitude of $5 \mathrm{~m}$ is attained during $10 \%$ of the time, and wave period varies between 8 and 15 s. (Castaing, 1981).

\section{2 - Morphology and facies zonation within the Gironde incised-valley}

The Gironde estuary is a typical wave -and tide- dominated estuary (Dalrymple et al., 1992) characterised by a tripartite morphological zonation comprising the fluvial sourced bay-head delta (that consists of the tidal-fluvial meandering channels and the zone of elongated tidal bars), the central basin containing muddy sediments and the estuary mouth with a deeply scoured tidal inlet terminating seaward and landward in sandy delta shoals (large ebb-tidal delta corresponding to the distal end of the tidal channel; Allen and Posamentier, 1994).

Two facies transitions have been observed in the present estuary (Allen and Truilhe, 1987; Allen, 1991) : (1) the fluvial gravel to tidal estuarine sand and mud transition at the landward limit of the estuary, and (2) the estuarine mud to marine sand transition at the estuary mouth. The mud to sand transition at the estuary mouth marks the point of convergence of the seaward prograding estuarine muds and the landward-migrating sands of the estuary mouth. Both of these facies transitions are preserved within the valley fill.

\section{Very High resolution seismic acquisition and processing}

Data were obtained during PLABAS cruise in May 1994 and completed during PLACETA cruise in June 1995 on the R/V "Thalia". The seismic lines have been acquired near the Gironde mouth (Fig. 1) in order to determine if an offshore prolongation of the Gironde incised-valley exists seaward on the shelf, and if this valley incises the shelf till the shelf-break.

Precise positioning was given by a DGPS system. The navigation was with an accuracy of a few metres and the lines were shot at a speed of 5 knots. The Very High Resolution 
(VHR) seismic reflection source was a single channel Sparker (SIG), with a central frequency around $800 \mathrm{~Hz}$ and a shooting rate of 1 shoot per second. The digital acquisition of single channel data was done in real-time on the ELICS DELPH PC based system (Girault and Mathevon, 1990). Due to very important swell at sea, the quality of the lines acquired in the vicinity of the estuary mouth was extremely poor. The data were processed with SITHERE processing software (Lericolais et al., 1990) with swell removal and deconvolution. During this survey, swell filtering and multiple removal were very useful for the determination of the key stratigraphic surfaces which were hidden by the water bottom multiple (Fig. 2).

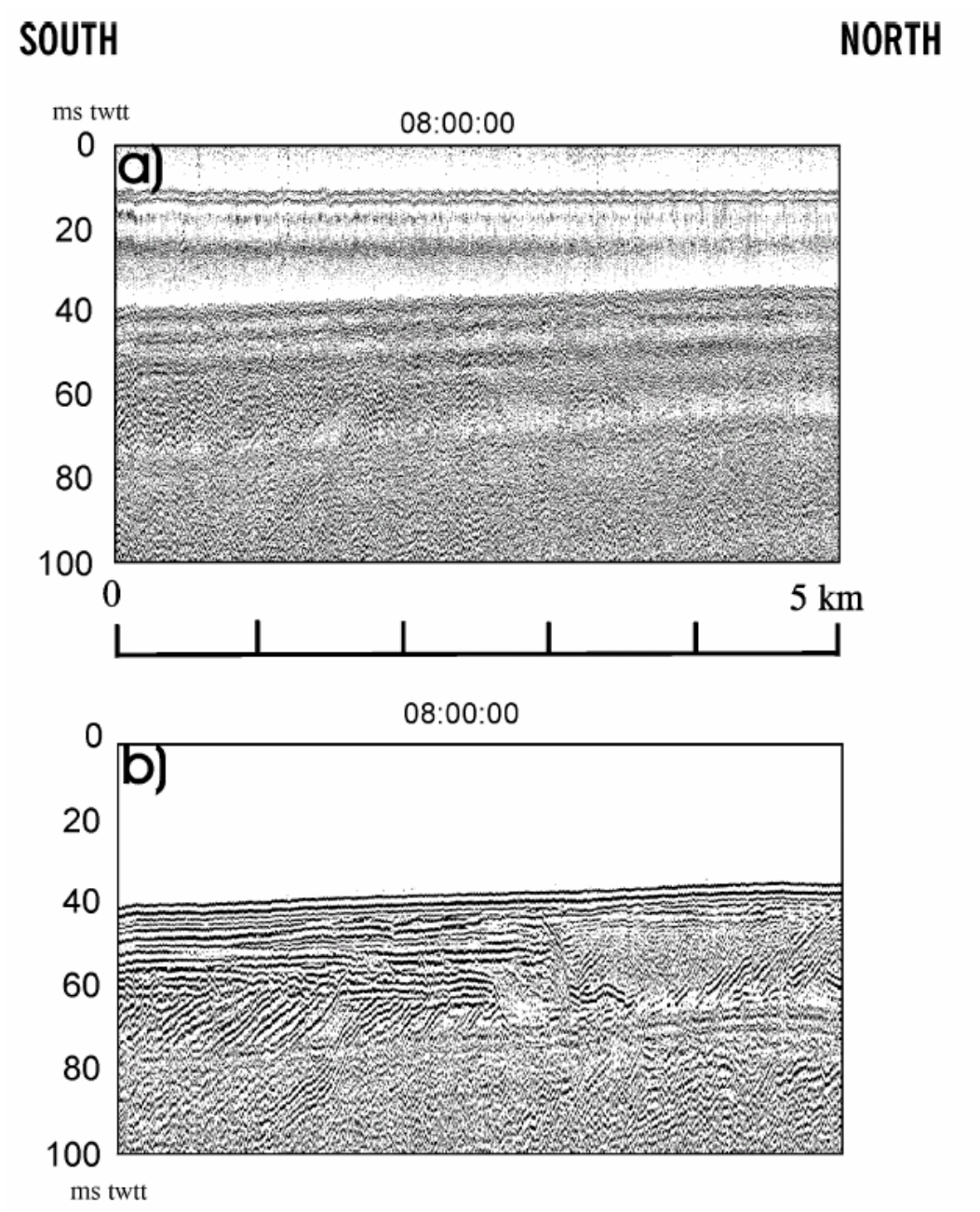

Figure 2 : Detail of seismic line 45

a) Unprocessed line (except AGC) showing the importance of the wave energy outside the Estuary and how impossible it is to determine the real depth of incision which is mixed with the first multiple.

b) swell filtered and homomorphic deconvoluted. 


\section{Description of the seismic lines}

\section{1 - Seismic analysis method}

Analysis of the reflection terminations (erosional truncation, onlap, downlap) and of reflection configuration (i.e. acoustic facies) allowed identification of small-scale seismic units and their boundaries. The seismic units and their discontinuities were numbered. Chiocci et al. (1991) and Browne (1994) have shown that, in some cases the general concepts of seismic stratigraphy (Mitchum et al., 1977) may be applied to high resolution date set. However, it must be emphased that inferences in terms of processes can generally not be applied in the same way for low resolution seismic data because scales of investigations are very different. For instance, autocyclic processes such as tidal inlet migration or intrinsic fluvial thresholds (Schumm, 1973) will have greater effect at the highresolution scale. 


\section{2 - VHR seismic section perpendicular to the axis of the incised valley}

Profile 45 (Fig. 3), shot in a water depth of $35 \mathrm{~m}$, is $35 \mathrm{~km}$ long and is located $10 \mathrm{~km}$ seaward of the estuary mouth. The NNW-SSE orientation of this line is perpendicular to the axis of the inlet of the Gironde estuary.

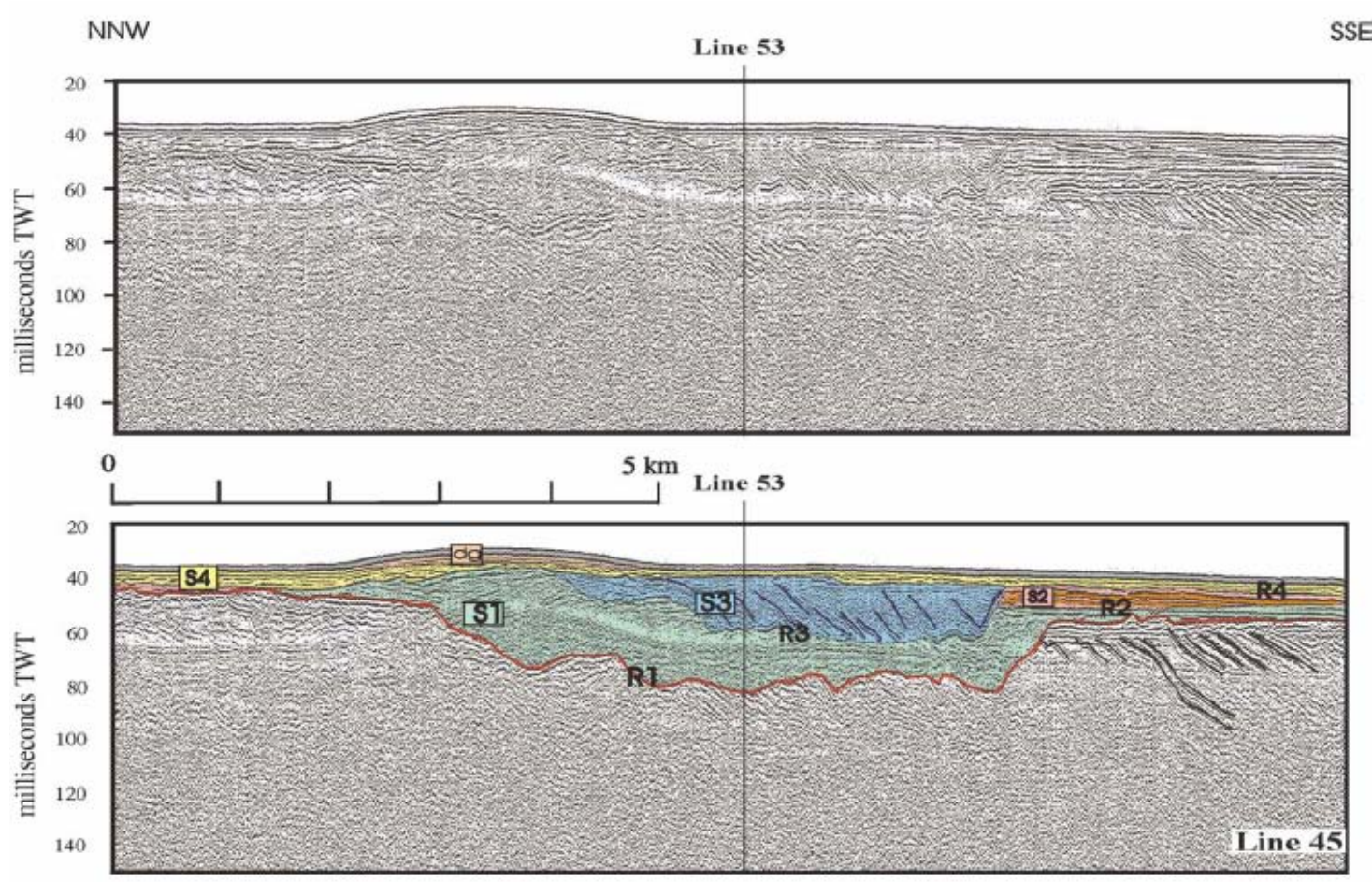

Figure 3 :Seismic line 45 processed and its interpretation. only $12 \mathrm{~km}$ of the line are presented R1 = Sequence Boundary, R2 = Transgressive Surface, R3 = Tidal Ravinement Surface, R4 = Wave Ravinement Surface, S1 = Lowstand Systems Tract, S2 = Transgressive Systems Tract, S3 = Tidal Infill (TST member) , S4 = Highstand Systems Tract, dg = Dredging dumping

This line presents a valley incision (more than $30 \mathrm{~m}$ deep) into Paleogene sediments which are identified by their characteristic seismic facies, high amplitude and dipping reflectors due to the alternation of mudstone and limestone (Alvinerie et al., 1967; Cirac et al., 1997). The seismic reflection R1 is an erosional unconformity at the base of unit S1. This unit consists of chaotic seismic facies, characterised by high amplitude, contorted reflections having poor lateral continuity and local burst of high amplitude. The upper boundary of this seismic sequence is reflection R2, which is a non erosive discontinuity. 
Above it, the sequence S2 shows relative high frequency continuous tabular reflections which onlap onto the underlying R2 surface in the southern part of the profile 45 (Fig. 3).

Reflection R3 is an erosional discontinuity cutting across unit S2 and S1. Above it, S3 is characterised by low-to moderate-amplitude and fair-to moderate-continuity reflections presenting gentle southward downlaps at base. The slope angle of these reflections is estimated to be around $2.5^{\circ}$.

On the northern and southern sides of the incision, R3 is truncated by the erosive surface R4 present all along the line. Above it, unit S4, consists of subparallel reflections with fair amplitude and continuity, and high frequency. 


\section{3 - VHR seismic section parallel to the axis of the incised valley}

Profile 53 is oriented WSW-ENE, and is perpendicular to profile 45. It has been shot in a water depth ranging from $10 \mathrm{~m}$ to $90 \mathrm{~m}$ in a seaward direction. It is oriented parallel to the axis of the inlet of the Gironde estuary. One section of this profile is presented Figure 4.

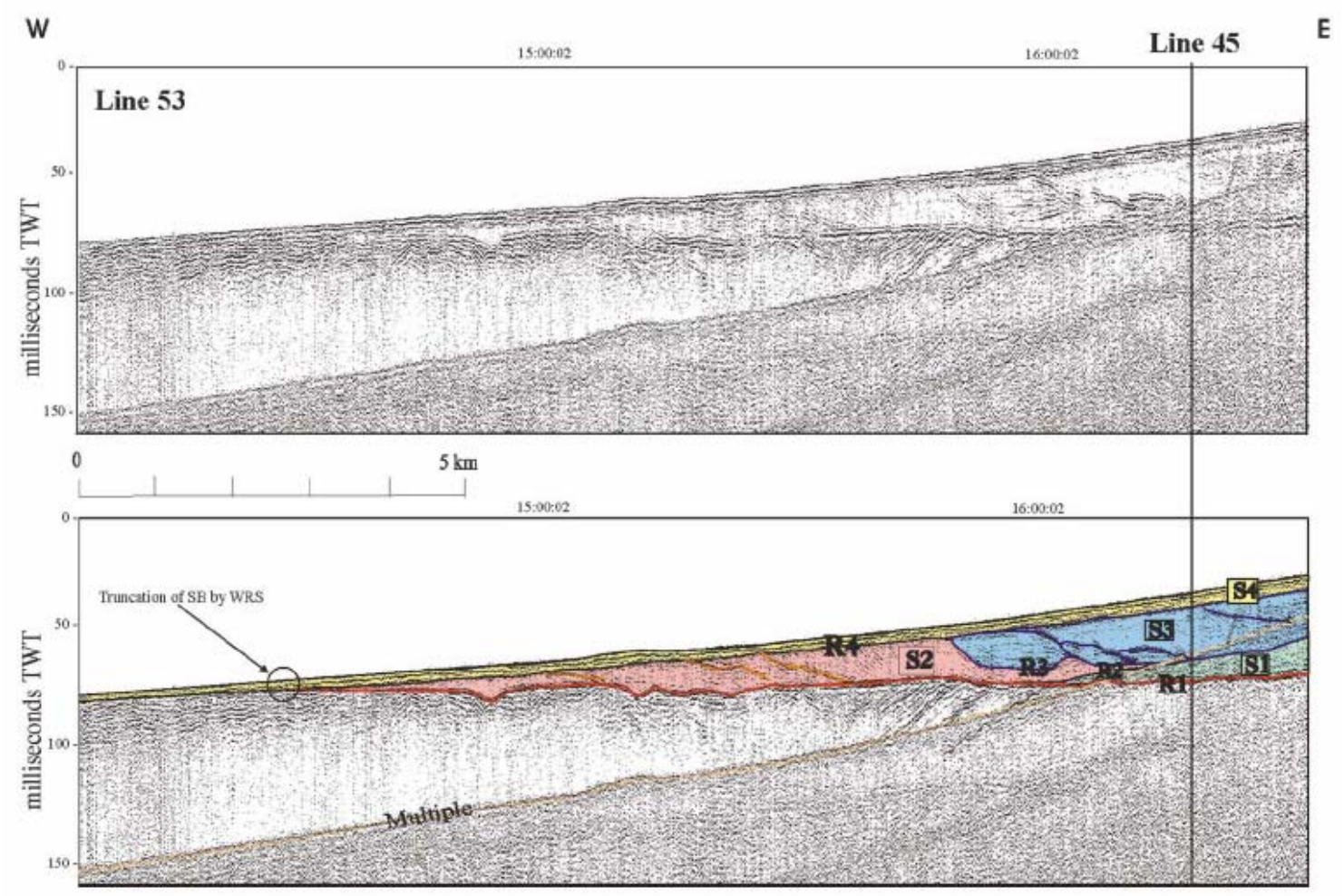

Figure 4 :Seismic line 53 processed and its interpretation.

R1 = Sequence Boundary (SB), R2 = Transgressive Surface (TS), R3 = Tidal Ravinement Surface (TRS), R4 = Wave Ravinement Surface (WRS).

Lowstand Systems Tract : represented by S1,

Transgressive Systems Tract :

Lower TST = unit S2 constituted of retrograding clinoforms (sigmoïdal shape) bounded by non erosive surface,

Upper TST = unit S3 constituted of clinoforms bounded by erosive surfaces, here Tidal Ravinement Surfaces, corresponding to a multi-storey tidal inlet infill.

Highstand Systems Tract : S4 with downlaping strata

On this profile, the reflection R1, which corresponds to the erosional surface cut into the Tertiary sediments, is observed on the eastern and central part of the line. On the western part of the line, this surface is truncated by the R4 surface. This truncation occurs in a water depth of around $60 \mathrm{~m}$, at $50 \mathrm{~km}$ to the west of the estuary mouth. The depth of $\mathrm{S} 1$ incision 
can reach more than $30 \mathrm{~m}$ deep into the Tertiary sediments, the overall funnel-shape of this erosional surface is illustrated by the 3D presentation of the lines 45 and 53 (Fig. 5). The overlying unit S1 is only present in the eastern part of the line, it is characterised by highamplitude contorted reflections as in the profile 45.

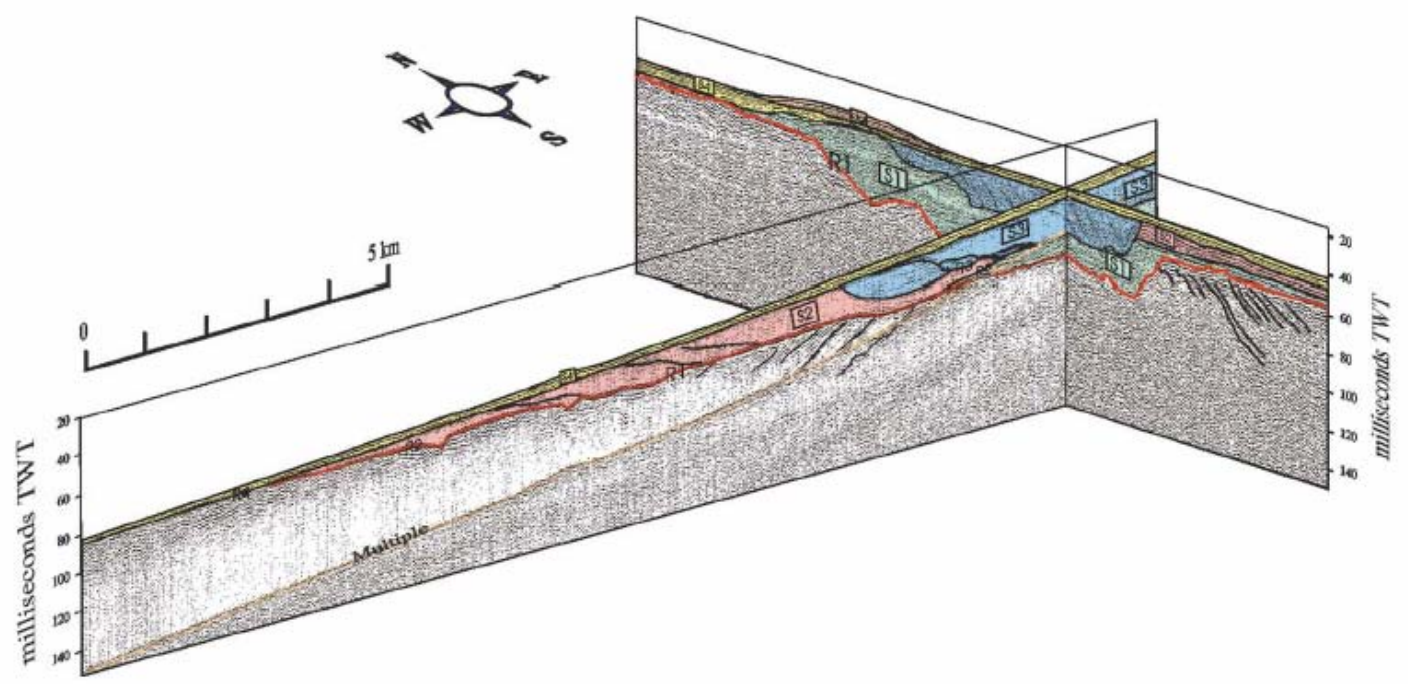

Figure 5 :Fence diagram of seismic lines 45 and 53.

In the central part of the line, R2 merges with the R1 surface (and is truncated by the R4 surface in the western part of the line). S2 has been deposited directly onto the R1 surface in the central part of the line. S2 is internally composed of 3 retrograding clinoform packages presenting a sigmoidal shape and bounded by non-erosive surfaces. These packages are characterised by landward-dipping low-to moderate-amplitude reflections.

R3 surface is a multi-storey erosional discontinuity composed of amalgamated erosional surfaces. It is the base of unit S3, which is internally composed of retrograding clinoform packages presenting a very irregular shape (each of which is eroded by the most recent one). The S3 seismic facies is characterised by low - to moderate - amplitude, fair - to moderate continuity and internal reflections slightly channelized.

R4 surface is an erosional discontinuity present all along the profile which truncates the underlying R1, R2 and R3 surfaces. Above it, the unit S4 displays subparallel reflections 
characterised by fair amplitude, excellent continuity and high frequency. The lower reflections rest on top of S2.

\section{Sequence stratigraphy interpretation (Fig. 6)}

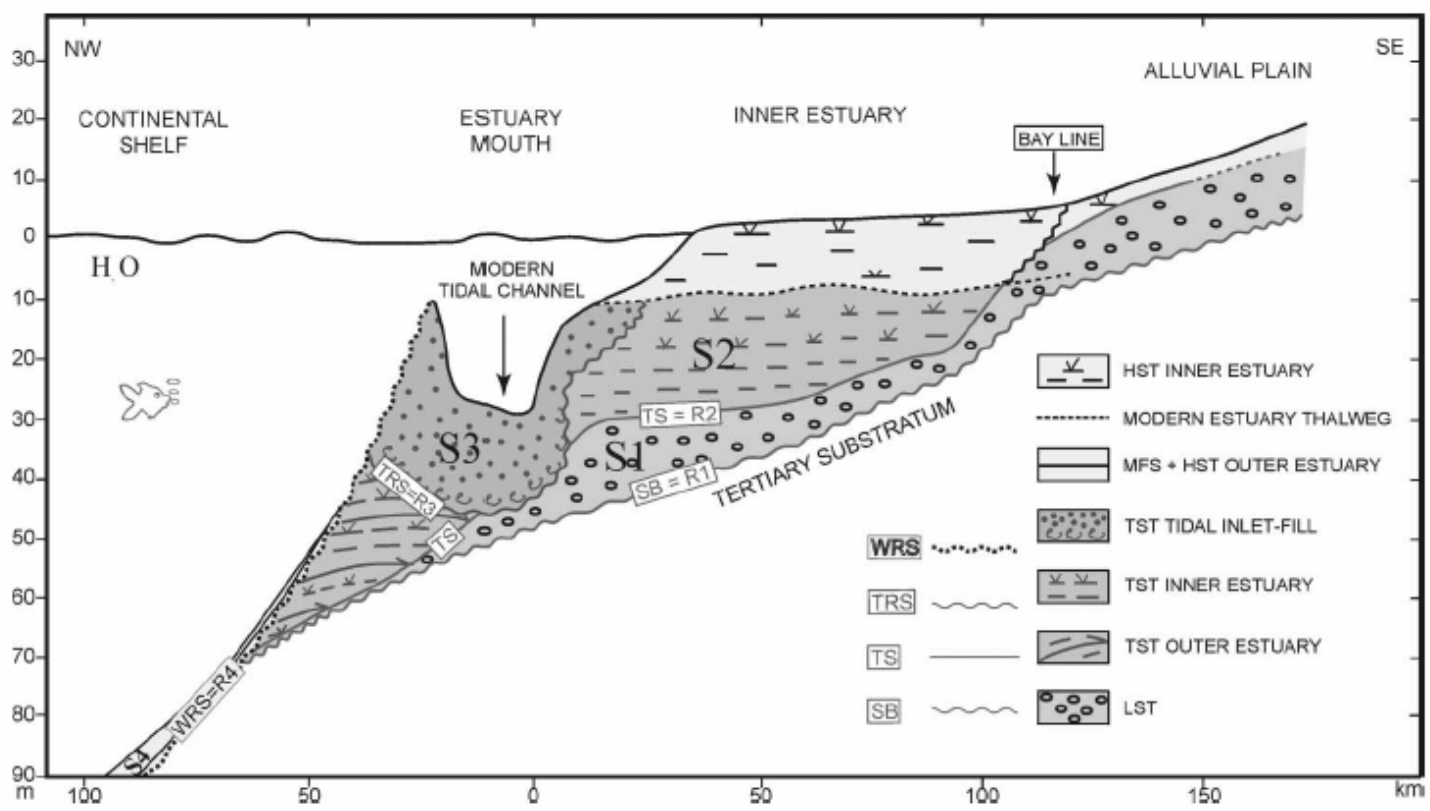

Figure 6 : $\quad$ Internal stratigraphy and seaward pinch out of the Gironde incised valley fill. Modified from Allen and Posamentier (1993,1994).

WRS = Wave Ravinement Surface (R4), TRS = Tidal Ravinement Surface (R3), TS = Transgressive Surface (R2), SB = Sequence Boundary (R1).

HST $=$ Highstand Systems Tracts (S4), MFS = Maximum Flooding Surface, TST = Transgressive Systems Tracts (S2 and S3), LST = Lowstand Systems Tracts (S1).

The seismic profiles shot outside the estuary mouth prolonged the inner estuary studies and the model obtained from core and borehole analysis made by Allen and Posamentier (1993, 1994). We have correlated the presented seismic sections with their model and used their sequence stratigraphy study as reference. In 1997, Cirac et al. have published interpretation of lines 46 and 48 located westward of the present studied area and have suggested that the sedimentary cover can be attributed to the undifferentiated Quaternary time period and only represents the Weischelian period.

The basal unconformity R1 cuts into the Tertiary carbonates and erode around $25 \mathrm{~m}$ of sediments near the mouth of the estuary ; $50 \mathrm{~km}$ westward along the valley axis, the depth of 
erosion decreases and is gradually reduced to less than a few meters before to be truncated by R4. R1 is interpreted to be a sequence boundary generated by fluvial incision during a sea-level fall. The decreasing depth of erosion observed from East to West on the profile 53 is attributed to the change of fluvial channel morphology : deep erosion is thought to have been generated by straight to meandering large channels and shallow erosion by anastomosed smaller channels. The seismic unit S1 is thought to be the Lowstand Systems Tract constituted of massive fluvial gravels and coarse sands described in the estuary mouth (Feral, 1970). Nearby the mouth of the estuary (profile 45), this unit is preserved in the thalweg of the incised-valley as described by Allen and Posamentier (Fig. 5b, p: 382 ; 1993). It is thought to be in continuity with the fluvial Lowstand deposits described onshore by the above authors. Seaward, along the valley axis (profile 53), this unit is not present on the R1 sequence boundary : the Lowstand Systems Tract has not been deposited or has been eroded off the distal part of the incised valley.

In the distal part, the R2 surface merges with the R1 surface, R2 is interpreted to be the transgressive surface (Posamentier et al., 1988a and b) bounding the base of the Transgressive Systems Tract. Eastward, towards the mouth of the estuary, this surface which separates the Lowstand Systems Tract from the Transgressive Systems Tract is eroded by R3 surface. The landward prograding clinoforms of the unit S2 are thought to be the estuarine parasequences of the Transgressive Systems Tract bounded by non-erosive flooding surfaces. Their maximum thickness is around $15 \mathrm{~m}$ to $20 \mathrm{~m}$, and they should be constituted of estuarine coastal plain mud and tidally-influenced sandy point bars.

The R3 multi-storey erosional surface, which cuts into the S2 and S1 units, is interpreted to be the amalgamation of 4 tidal-ravinement surfaces (Allen, 1991) generated by the landward migration of the tidal inlet in the estuary mouth during the transgression, as described by Allen and Posamentier (1994). The depth of incision of R3 is around $30 \mathrm{~m}$. The irregularly-shaped clinoforms should be constituted of coarse-grained tidal inlet sands bounded at their base by gravels lags.

The R4 erosional surface, which truncated the R1, R2 and R3 surfaces, is interpreted to be the wave-ravinement surface (Swift, 1968). The unit S4, composed of widespread 
reflections, is thought to be the early Highstand Systems Tract with the Maximum Flooding Surface on top. This unit, which has been cored on the shelf (Collotte, 1985 ; Lesueur and Tastet, 1994), is a few meters thick and is composed of silts and muds, brought offshore onto the shelf by the Gironde during the winter floods, and of sands eroded off the shelf during the storms.

\section{Discussion}

\section{1 -Seaward pinching out of the Lowstand Systems Tract}

Profile 53, shot in the axis of the Gironde incised valley, shows a rapid pinching out of the valley, and a progressive decrease of depth of incision of the sequence boundary (R1), which is eventually truncated by the wave-ravinement surface (R4) $50 \mathrm{~km}$ seaward of the estuary mouth.

The poor development of the Lowstand Systems Tract, which is conform to what is described in the thalweg of the Gironde estuary (maximum thickness : less than $20 \mathrm{~m}$ ), is due to the absence of fluvial aggradation during the Lowstand times (Allen and Posamentier, 1993). Moreover, the decreasing depth of incision of the sequence boundary in a seaward direction, which is interpreted to be caused by a change in channel morphology (large sinuous deep channels become smaller anastomosed shallower channels), may be due to the unability of the fluvial system to prograde fast enough to catch up with the seal level drop. Similar observations have been reported by Van Wagoner (1995) on the Cretaceous strata of the Book Cliffs formation (USA). The result of such a process is that the Lowstand incisedvalley deposits are disconnected from the Lowstand deposits located on the shelf break described by Cirac et al. (1997).

\section{2 -Lower Transqressive Systems Tract below the tidal-ravinement surface (unit S2)}


Profile 53 shows that the seaward part of the Transgressive Systems Tracts, unit S2, constituted of landward-migrating clinoforms downlapping landward directly onto the sequence boundary (R1), or onto the transgressive surface (R2). These clinoforms are bounded by non-erosive flooding surfaces and their thickness increase landward up to $15 \mathrm{~m}$, which is comparable to the thickness of the estuarine Transgressive Systems Tract sediments within the inner estuary (Allen and Posamentier, 1993).

The landward extremity of each clinoform is thought to be the bay line, the length of the clinoform represents the length of the estuarine sediment wedge along the axis of the incised-valley (between the mouth of the incised-valley and the bay line). The progressive increase of volume of each estuarine clinoform in a landward direction may be due to the progressive decrease of the ratio between the rate of relative sea -level rise and the rate of fluvial sediment influx in the estuary (i.e. : the ability of the fluvial sediments to fill the available estuarine space was greater as the rate of relative sea-level rise slowed down).

In such a wave - and tide - dominated environment, a tidal-ravinement surface and the associated tidal inlet deposits should be expected on the top of these estuarine clinoforms, which is not the case on the profile 53. The absence of the tidal inlet deposits here could be due to the fact that they were only deposited in the distal extremity of the valley. This part of the valley is often characterised by a network of small and shallow anastomosed Lowstand channels. So when the sea level rise reached the distal extremity of the Gironde incisedvalley, flooding of the shallow channels would not increased the oceanic tidal range because tidal flows were not constrain into one single deep estuarine channel. In that case, the tidal inlet deposits would have been deposited where the estuarine channel is not unique; at its dsital extremity. Here, may-be because of the relative weakness of the tidal currents, tidalravinement seemed not to have occurred. The morphology of the Lowstand fluvial channels seems to have controlled the sedimentary processes and the internal architecture of the early Transgressive Systems Tract deposits (i.e. : phase 1 of the TST ; Allen and Posamentier, 1994). 


\section{3 -Upper Transgressive Systems Tract above the tidal-ravinement phase (Unit S3)}

On profile 53, the landward part of the Transgressive Systems Tract (sequence S3) is constituted of a multi-storey landward-migrating tidal channel deposits bounded by a tidalravinement surface. These deposits are around $30 \mathrm{~m}$ thick, which is comparable to the present-day water depth of the tidal inlet at the mouth of the estuary (around $35 \mathrm{~m}$ deep).

This type of incision occurred in the proximal part of the incised-valley when the rising sea level flooded the deep and large lowstand fluvial channel located upstream of the small shallow anastomosed fluvial channels. In this setting, the oceanic tidal range was locally amplified at the spit-constricted estuary mouth and strong tidal currents scoured deeply into the underlying estuarine sediments (Castaing, 1981). During the transgression of the estuary, the landward migration of the tidal inlet resulted in a complete erosion of the underlying early Transgressive Systems Tract sediments (phase 1), which are not observed in this proximal part of the Gironde incised valley.

As the prognosis made by Allen and Posamentier (1994), these late Transgressive Systems Tract sediments (phase 2) constitute the bulk of the incised valley-fill in this wave and tide - dominated environment. They form a continuous unit present offshore and onshore in the estuary, bounded at its base by the tidal-ravinement surface which extends $15 \mathrm{~km}$ seaward of the estuary mouth to $10 \mathrm{~km}$ landward within the present-day Gironde estuary.

\section{4 -Hiqh Stand Systems Tract above the Wave Ravinement Surface and the Maximum Flooding Surface (Unit S4)}

The wave-ravinement surface (R4) is visible on profiles 53 and 45. This extensive surface, which has been generated during the transgression and the following Highstand, still forms today because the coastline is eroded by the wave action (average rate of coastal retreat : between $1 \mathrm{~m}$ and $2 \mathrm{~m}$ /year). Its erosional depth is estimated to be around $5 \mathrm{~m}$ (Lericolais et al., 1998). It does not totally erode the interfluve deposits outside off the 
valley axis (see profile 45) and it is weaker from what was prognosed by Allen and Posamentier (1994) - i.e. : the interfluve should have been totally eroded by the waveravinement surface -.

The Maximum Flooding Surface (MFS) is not directly visible on the seismic profiles ; it is the surface onto which the distal part of the early Highstand Systems Tract (HST) downlaps (see profile 53). The facies of the condensed section around the MFS and of the distal early HST sediments are very similar - fluvially sourced mud and silts, interbedded with wave-reworked marine sands. The distinction between these two stratigraphic units is based upon the strata geometry of the distal early HST which prograde and downlap westward.

Forty kilometres onshore within the Gironde estuary, the fluvially-sourced, seawardprograding bay-head delta sediments are the proximal Highstand Systems Track, which will eventually migrate down to the estuary mouth (Allen and Posamentier, 1993, 1994 ; Féniès and Tastet, 1998). 


\section{Conclusions}

The use of Very High Resolution seismic reflection offshore of the Gironde estuary mouth, and above all the use of seismic processing, have brought new facts concerning the seaward extension of the Gironde incised valley.

1 - The Gironde incised valley tapers $50 \mathrm{~km}$ seaward of the estuary mouth. The fluvial incision located at the base of the Lowstand Systems Tract decreases gradually seaward and is eventually truncated by the wave ravinement surface around - $70 \mathrm{~m}$ below the present-day mean sea level. The decreasing depth of incision of the sequence boundary is interpreted to be due to a change in the morphology of the fluvial Lowstand channels : large and deep sinuous channels located upstream change downstream to smaller and shallower anastomosed channels.

Similar observations have been made for the English Channel paleoriver (Lericolais et al., 1996; Lericolais, 1997), which supports the idea that rivers do not always generate continuous cross-shelf incised-valleys during the phase of sea-level drop. When sea-level drops too rapidly for fluvial sedimentation to keep pace with it, lowstand deposition occurs as prograding channels which eventually died out in the proximal part of the shelf. Similar mechanisms are observed in flume models (Koss et al., 1994) and underlie the need of application of geomorphic principles to sequence stratigraphic models (Wescott, 1993).

2 - Both, transversal and longitudinal seismic sections globally confirm the assumptions made by Allen and Posamentier $(1993,1994)$ concerning the stratigraphy of incised-valley fill on the shelf.

- The valley-fill contains a single sequence composed of three systems tract (LST, TST, HST). If the valley-fill is dated Weischelian (stage $2 ; 18,000$ years BP) as it has been dated in the estuary mouth (Allen, 1991), this sequence would correspond to a fifth-order cycle (Vail et al., 1991).

- The Lowstand is poorly developed in the proximal part of the incised valley and pinches out in its distal part ; no fluvial aggradation has been observed. The 
morphology of the Lowstand channels seems to have controlled the internal stratigraphy of the Transgressive Systems Tract.

- The Transgressive Systems Tract constitutes the bulk of the incised valley-fill in this wave - and tide - dominated environment. In the distal part of the incised valley, the lower TST strata (unit S2) are composed of landward-prograding estuarine clinoforms bounded by non-erosive flooding surfaces. These lower TST strata are not overlain by upper TST strata (unit S3) (i.e. : the tidal inlet-fill sediments). Their absence is attributed to the fact that, when the small and shallow anastomosed fluvial channels are flooded during the transgression, the oceanic tidal range is not amplified by a funneling effect within the incised valley, and consequently the tidal-ravinement process does not occurs.

Oppositely, in the proximal part of the incised valley, the upper TST strata (unit S3) are exclusively composed of landward-migrating tidal inlet deposits bounded by a tidalravinement surface. Such deposits were generated when the deeper and larger Lowstand channels have been flooded during the transgression. Here, the oceanic tidal range was locally amplified by the spit-constricted estuary mouth and the tidal-ravinement process started as described by Allen and Posamentier $(1993,1994)$ for the estuary mouth. The landward retreat of the estuary mouth within the incised-valley thalweg has totally eroded the underlying estuarine lower TST strata (unit S2).

- The Highstand Systems Tract is deposited upon a widespread, Wave-Ravinement Surface. This erosion, generated by the wave action on the shelf, is relatively weak (around $5 \mathrm{~m}$ deep) and it does not totally erode the interfluve deposits outside off the valley axis.

- The lower Highstand strata are relatively thin (a few meters), they prograde and downlap basinward upon the Maximum Flooding Surface. These strata will eventually be covered by the upper Highstand Systems Tract deposits, when the bayhead delta sediments will have filled the estuary funnel and prograde offshore outside of the estuary mouth. This subdivision is not time controlled, the upper HST is deposited in the estuary while the lower HST is forming on the shelf at present. This 
is strictly correlated with the situation onland (progradation on the valley, coastal retreat at the shoreline). 